\title{
Children's verbalizations of motion events in German
}

\author{
ANNE-KATHARINA OCHSENBAUER and MAYA HICKMANN*
}

\section{Abstract}

Recent studies in language acquisition have paid much attention to linguistic diversity and have begun to show that language properties may have an impact on how children construct and organize their representations. With respect to motion events, Talmy (2000) has proposed a typological distinction between satellite-framed $(S)$ languages that encode PATH in satellites, leaving the verb root free for the expression of MANNER, and verb-framed $(V)$ languages that encode PATH in the verb, requiring MANNER to be expressed in the periphery of the sentence. This distinction has lead to the hypothesis (Slobin 1996) that MANNER should be more salient for children learning S-languages, who should have no difficulty combining it with PATH, as compared to those learning V-languages. This hypothesis was tested in a corpus elicited from German children and adults who had to verbalize short animated cartoons showing motion events, and the results are compared with previous analyses of French and English corpora elicited in an identical situation (Hickmann et al. 2009). As predicted, and as previously found for English, German children from three years on systematically express both MANNER (in the verb root) and PATH (in particles), in sharp contrast to French children, who rarely package MANNER and PATH together. These results suggest that, when they are engaged in communication, children construct spatial representations in accordance with the particular properties of their mother tongue. Future research is necessary to determine the extent to which cross-linguistic differences in production

* Address for correspondence: A.-K. Ochsenbauer, Ludwig-Maximilians-Universität, Institut für Deutsche Philologie, Schellingstraße 3/RG, 80799 München. Email: anne. ochsenbauer@lmu.de M. Hickmann, CNRS Laboratoire Structures Formelles du Langage, UMR 7023, 59 rue Pouchet, 75017 Paris, France. Email: maya.hickmann@sfl. cnrs.fr 
may reflect deeper differences in the allocation of attention and in conceptual organization.

Keywords: cognitive linguistics, language acquisition, language typology, space, thinking for speaking, Whorfianism.

\section{Introduction}

During the last twenty years linguists and psycholinguists have postulated different ways of relating the process of children's language acquisition to their cognitive development. Predominant theories in psychology have put forth the existence of universal perceptual and cognitive constraints in language acquisition determining children's verbal production and comprehension (e.g., Piaget and Inhelder 1947, or Spelke 2003). However, recent studies (for example, Slobin 1996, 2003a, 2003b, 2006) indicate that our language seems to influence how "we think when we speak", for example inviting us to focus on particular aspects of reality. These results suggest that children learn to verbalize situations in a certain way, which is most typical of their mother tongue, and that they organize incoming information accordingly. The study described below further tests this hypothesis by examining how German children and adults express voluntary motion events in controlled experimental situations. A comparison of our results with those of previous comparable studies concerning English and French supports the claim that the linguistic properties of spatial systems influence how children construct their spatial representations.

\section{Space across languages}

Talmy $(1983,1985,1991,2000)$ has shown that languages show strikingly different lexicalization patterns in the expression of motion events, that are reflected in different ways of combining semantic information in surface structure. For example, as illustrated in (1) and (2), satellite-framed languages (e.g., Germanic) encode MANNER in the verb stem (English/ German swim/schwimmen, run/rennen) and PATH in verbal satellites ${ }^{1}$ such as particles (across/durch, away/weg). In contrast, as shown in (3),

1. In their draft, Croft et al. (2008) propose to expand Talmy's typology, taking into account lexicalization patterns that are less typical but occur regularly in a large number of languages, particularly three symmetrical types: coordination, serialization and compounding. 
verb-framed languages (e.g., Romance) encode PATH in the verb stem (traverser 'to cross', partir 'to leave') and MANNER by peripheral constructions such as adverbial phrases (à la nage 'with a swim') or gerunds (en courant 'by running').

(1) The child swims across the river

(2) Das Kind durchschwimmt den Fluss

and runs away.

'The child through-swims the river

und rennt weg.

(3) L' enfant traverse

and runs away.'

'The child crosses

la rivière à la nage et part en courant.

the river with a swim and leaves by running.'

When verbalizing a motion event, speakers choose among several means of expression those which are most typical for their language. One implication is that, while speaking, they are invited to focus on different aspects of reality, and therefore to foreground and background incoming information in different ways across languages. Slobin (1996, 2003a, 2003b, 2006) further tested some cognitive implications of Talmy's typology, pointing out three factors which increase the likelihood that speakers will express and/or combine particular semantic components. The first factor is finiteness. In satellite-framed languages (see German (4) and (5)) MANNER is normally expressed in the main inflected verb, or more precisely in that part of the main verb that carries verbal morphology. In contrast, speakers of verb-framed languages (see French (6) and (7)) have to use peripheral constructions that may include a non-finite verb. As a result, German (4) and (5) are of the same complexity, whereas (7) is more complex than (6) in French.

(4) Das Mädchen rennt über die Straße. 'The girl runs across the street.'

(5) Das Mädchen geht über die Straße. 'The girl goes across the street.'

(6) La fille traverse la rue. 'The girl crosses the street.'

$\begin{array}{llll}\text { (7) La fille traverse } & \begin{array}{l}\text { la rue en courant. } \\ \text { crosses }\end{array} \text { the street by running.' }\end{array}$

The second factor is lexeme frequency. In satellite-framed languages verbs expressing simultaneously MOTION and MANNER are extremely frequent and often used, even by young children. In verb-framed languages this kind of verb is less frequent. Finally, the last factor is the possibility of expressing information by means of a single (complex) morpheme rather than by a phrase or clause. Examples (8) to (10) illustrate several verb equivalents for some types of motion events in English, German and French, showing that German has many MANNER-verbs which have 
no monolexematic equivalent in French and sometimes not even in English:

(8) schlurfen, to shuffle along, traîner les pieds

(9) stapfen, to plod, marcher à pas lourds

(10) tappen, to go falteringly, marcher d'un pas maladroit

Each of these three factors makes it easier for speakers of satelliteframed languages to express MANNER and PATH together in one single clause as compared to speakers of verb-framed languages. As a result, one implication is that MANNER should be more salient in these languages than in verb-framed languages. In contrast, no difference in salience across languages is predicted for the semantic component PATH. From a developmental point of view, it might also be predicted that these typological differences should result in different developmental progressions during the acquisition of spatial language. Thus, Slobin suggests that each language should invite children to focus on some specific aspects of spatial representations. As a result, they may gradually take a particular perspective on the world, which may influence not only how they verbalize motion events, but perhaps also their cognitive organization more generally.

Although German stands among other satellite-framed languages, few studies have examined in detail how motion is expressed in this language. One study (Tschander 1999) shows that available classifications of motion verbs (Talmy 1985; Landau et al. 1993) are too simplistic. Apart form German verbs containing either MANNER or PATH, this study postulates a third category, namely PATH-MANNER-verbs (e.g., humpeln 'to hobble') which describe a 'combined movement' (kombinierte Bewegung). These verbs are used with different auxiliaries depending on the speaker's focus: with the auxiliary haben ('to have') they focus on MANNER; with the auxiliary sein ('to be') they focus on PATH. Example (11) taken form Tschander's article demonstrates this phenomenon:

(11) Debbie hat/ist gehumpelt.

'Debbie has/is hobbled.'

According to Tschander, these two concepts of movement, MANNER and PATH, must not constitute separate entries in the lexicon, so that these verbs should correspond to only one entry in the lexicon. Weber (1983) also proposes a more detailed classification of German motion verbs based on several recurrent semantic components. On the basis of a sample of 90 motion verbs, he extracts 35 semantic components, 20 of which actually correspond to some aspect of MANNER that characterizes most 
verbs (94\%). This analysis shows again that German encodes MANNER in the vast majority of its motion verbs.

With respect to satellites, there is no consensus as to the nature of this class in German. According to Talmy (1991: 486), satellites belong to

"[...] the grammatical category of any constituent other than a nominal complement that is in a sister relation to the verb root. Satellites can be either a bound affix or a free word, and encompass very diverse grammatical forms (English verb particles, German separable and inseparable verb prefixes, $[\ldots$....)."

Haggblade's (1994) analysis of German satellites includes a variety of devices, among which the following four classes will be most relevant below: 1) prefixes, e.g., über- in überqueren ('to cross'); 2) particles, e.g., rauf- in raufklettern ('to climb up') 3) prepositional phrases, e.g., auf den Baum ('on the tree'); 4) adverbs, e.g., hinauf ('up'). ${ }^{2}$ A more detailed discussion of the problematic distinction between German prefix- and particle-verbs can also be found in Altmann and Kemmerling (2005: 63ff). For example, they propose a particle type called "double-particle" (e.g., drauf- 'up there' or herunter- 'down from there'), which add some deictic (and sometimes local) information to their directional component.

\section{Universal and language-specific determinants of children's spatial language}

With respect to the relation between language and cognition during child development, one of the most important research questions is whether children construct universal pre-linguistic concepts that underlie language acquisition or whether their concepts are substantially structured or transformed with the emergence of language. During the last years, this question has been approached by linguists and psycholinguists by and large in three different ways.

Proponents of a first position claim that the language ability is innate, modular, and domain-specific. In this view neither general cognitive faculties nor language acquisition have any substantial influence on this initial knowledge. According to Spelke (2003), human language only provides the opportunity to combine knowledge from different modules, allowing humans to build representations that are more complex than

2. In some verbs stress is a criterion to distinguish between prefix and particle verbs, e.g., überfáhren ('ton run over') and überfahren ('to cross over'), where accents on vowels mark stressed syllables in the verb. 
those of other species. The second position is perhaps best illustrated by Piagetian theory, which argues that perceptual and cognitive constraints determine language acquisition. Many studies have indeed shown that universal perceptual and cognitive factors influence concept formation and determine which spatial dimensions are most salient (Antell et al. 1985, Mandler 1996). Such factors account for the recurrent order in which linguistic procedures are acquired and related concepts constructed by children across languages. For example, in a review of studies on the acquisition of spatial prepositions across several languages, Johnston and Slobin (1979) showed that all children first learn prepositions that encode containment (in), support (on) and occlusion (under), then those that encode proximity (next to), and at last those that refer to distinctions on the sagittal axis (behind, in front of ). This recurrent order reflects the relative complexity of spatial markers and suggests that universal cognitive constraints influence acquisition.

Finally, according to the position known as linguistic determinism (Whorf 1956; Bowerman 1996; Slobin 1996), our language influences how we think when we talk, getting us to focus our attention on particular aspects of reality. Thus, children learn to verbalize situations in a certain way, that is most typical for their mother tongue. In particular, different lexicalization patterns across languages (e.g., pre- and postpositions, particles, morphologically complex forms or synonyms) influence how children acquire spatial language. Several studies (Bowerman 2003; Choi and Bowerman 1991; Hickmann 2006, 2007; Hickmann et al. 2009) have shown that children talk about space more like adults who speak the same mother tongue than like children of the same age learning a typologically different mother tongue.

For example, from very early age on, English-speaking children express the MANNER and PATH of motion together in one single clause because their language possesses very compact structures allowing them to do so easily. In contrast, although it is possible to express MANNER and PATH together in French, and although French adults do combine these two types of information in some situations, they do so less frequently and less systematically than English adults. In addition, French children (three to ten years) rarely express both components together, presumably because this kind of response requires more complex structures in French than in English. Finally, at all ages French speakers' responses vary with event types: although they typically focus on PATH with most events, they also focus on MANNER with crossing events (children) or combine PATH and MANNER with upward motion (mostly using the verb grimper 'to climb up', that lexicalizes both). These results directly follow from the typological properties of English and French, suggesting that children learn very 
early to express the types of information that are salient in their native language. Therefore, both general and language-specific determinants influence children's cognition and language in the domain of space.

As noted above, despite some particular properties of German, its lexicalization pattern for motion events is similar to the one in English since most German motion verbs conflate MOTION and MANNER, while PATH is typically expressed in a wide range of satellites (particles, adverbs etc.). From a developmental point of view, German children should therefore talk about motion more like English-speaking children (frequent MANNER verbs and PATH satellites) than like French-speaking children (frequent PATH verbs, infrequent MANNER). This hypothesis is partially supported by some scant available evidence. One study (Bamberg 1994: 221) notes that German children make heavy use of varied motion verbs and satellites in narrative discourse, but provides no further information concerning how these devices are used. Evidence from a study (Gentner 1979) concerning early child English shows the frequent use of 'light' verbs in combination with satellites, which may also be expected to occur among German children. Light uses need not involve the full meaning of verbs, which can be frequently reduced to sheer motion (e.g., gehen 'to go' rather than 'to walk'). Such uses presumably also involve a lower level of grammatical complexity since children often learn the finite forms of these verbs by rote and therefore do not actively inflect them. Example (12) illustrates a construction of this type (light verb gehen, verb particle rauf 'up') which is very frequent among young German children.

(12) Er geht rauf.

'He goes up.'

With respect to German, surprisingly little is still known concerning children's uses of other devices outside of the main verb root, such as those illustrated in (13) to (17) below: spatial adverbs, spatial particles, prefixed verbs, and full prepositional phrases which govern either Dative or Accusative case to distinguish general locations from changes of locations, respectively.

(13) Der rennt hier. 'He runs here.'

(14) Die geht rauf. 'She goes up.'

(15) Die Frau überquert die Straße. 'The woman crosses the street.'

(16) Der Affe klettert auf den Baum. 'The monkey climbs on the[Acc] tree.'

(17) Das Kind spielt in der Küche. 'The child is playing in the[Dat] kitchen.' 
The present study aimed at further examining how German children represent motion events in a controlled experimental situation that was similar to the one previously used for English and French (Hickmann 2006; Hickmann et al. 2009). Given the properties of German, the following predictions were made. First, from the youngest age tested (three years) onwards, German children should express both MANNER and PATH, relying on structures that encode MANNER in the verb and PATH in other devices such as particles, which represent the typical typological pattern of satellite-framed languages. Second, they also should use a great number and variety of motion verbs expressing MANNER, since such verbs are frequent in the adult input (Talmy 1985, 2000; Weber 1983). Third, their uses of devices outside of the verb root should show some change with age as a function of grammatical complexity. In particular, children should produce these devices in the following order: first particles and adverbs, which are least difficult because they do not require any inflection ${ }^{3}$; then prefixed verbs, which are possible means of expressing motion; and finally, full prepositional phrases, which govern different case markings.

\section{Method}

\subsection{Subjects}

The results reported below concern 60 monolingual Germans in five age groups (12 subjects per age). Four groups of children, boys and girls, were tested in kindergartens and primary schools of Augsburg. Their ages were approximately three years (mean $3 ; 8$, range $3 ; 4$ to $4 ; 4$ ), four years (mean $4 ; 7$, range $4 ; 6$ to $5 ; 4$ ), six years (mean $6 ; 7$, range $6 ; 4$ to $7 ; 2$ ), and ten years (mean 10;5, range 10;4 to 10;11). A control group of adults involved students from the University of Munich.

\subsection{Materials}

Two sets of animated cartoons were constructed (see Appendix). In all cartoons characters carried out a displacement in a particular MANNER (e.g., walking, running, jumping, etc.), then left the scene. One set of target items (six up-targets and six down-targets) showed a scene with a vertical ground referent, along which displacements took place (e.g., a squir-

3. Particles are used very early in German (e.g., Auto rauf 'car up'). Later in development they are integrated into particle verbs and then form part of the Satzklammer (sentence bracketing) which is syntactically more complex and thus more difficult to learn (e.g., Ich schieb das Auto rauf. 'I push the car up.'). 
rel running up/down a tree and away). In another set of items (six control items) the characters entered onto one side of the scene against a blank screen, moved to the other side, and left. MANNER corresponded to the types of actions that took place in the target items during the characters' departure (e.g., walking). These displacements were carried out in the absence of any scenery that could provide specific relevant ground entities for the expression of PATH.

Upward and downward motion was selected as targets for the stimuli because they correspond to events that are most familiar to children 4 . Furthermore, the addition of control items provided a direct contrast between two conditions. Target items focused subjects' attention on location changes that involved relevant MANNER and PATH information, whereas control items minimized PATH information and highlighted MANNER. It was expected that German subjects should 1) express MANNER with both types of items, but 2) combine MANNER and PATH with target items and 3) do so more often with increasing age. Control items also provided a way of determining whether children were able to produce some MANNER information, particularly if they had not spontaneously mentioned this information when describing target items.

\subsection{Procedure}

Subjects were seen individually in their school or university setting. They were presented the cartoons on a computer screen and asked to narrate each cartoon as completely as possible. The entire session was audiotaped. Primary school children and adults were told that a future addressee, who would not be shown the cartoons, would have to reproduce the stories on the basis of the recordings. Younger children were introduced to a doll and were asked to blindfold her as part of a game in which they would be telling her secrets. They were reminded throughout to tell her everything that had happened because she could not see and would also like to tell the story. This procedure ensured that subjects produced full descriptions. Cartoons were presented in six different random orders in which target items always occurred before control items. A training item began the session.

4. The stimuli actually included six other cartoons that were interspersed among the target items, but are not discussed in the present paper because of space limitations. This additional set of stimuli showed events that involved crossing a boundary (e.g., a baby crawling across a street, a boy swimming across a river). All results concerning these events are entirely in line with those reported here for up/down events. 


\subsection{Coding}

The analyses focused on utterances that described motion. These utterances contained several types of information relevant to motion that were encoded by a variety of linguistic devices, grouped below into two classes: main verbs vs. all other devices. With respect to main verbs, the coding first distinguished those that were potentially light, particularly all verbal forms of gehen ('to go'), from all others that had their full semantic meaning (e.g., rennen 'to run', hüpfen 'to jump'). Most uses of gehen ('to go') presumably expressed sheer motion, rather than a particular MANNER of motion, given that the corresponding experimental item did not at all show walking (e.g., cyclist in example (18)). Motion verbs other than gehen were further coded with respect to PATH (e.g., kommen 'to come') and MANNER (e.g., hüpfen 'to jump'). Devices outside of the main verb were of three types: 1) prepositional phrases (e.g., auf den Baum 'on the tree'); 2) spatial particles (e.g., rüber 'across'); 3) other relevant expressions like adverbs (e.g., hier 'here'). They were further coded in terms of whether they expressed PATH (e.g., weg 'away'), MANNER (e.g., auf allen Vieren 'on all fours'), and other types of information, for example locations (e.g., da 'there'). ${ }^{5}$

$\begin{array}{llll}\text { Die Fahrradfahrerin, die } & \text { geht da rüber. } \\ \text { 'The woman-cyclist, she goes there } & \text { across.' }\end{array}$

\section{Results}

\subsection{Up and down motion}

5.1.1. Main verbs. As expected, young children frequently produced the light verb gehen ('to go') in combination with various other devices, particularly at ages three to six (34\%). Light verbs then decrease sharply at ten years $(8 \%)$ and practically disappear in the adult group $(2 \%)$. As illustrated in example (19), the meaning of gehen ('to go') as light-verb can be reduced to sheer motion.

(19) Der geht dahin und geht da hoch, frisst den ganzen Honig, wieder runter und geht dann weiter. (3 years)

'He goes there and goes there up, eats all the honey, again down and goes then along.'

5. Our data showed no verbal root conflating both MANNER and PATH, nor any subordinated clauses expressing motion information. 


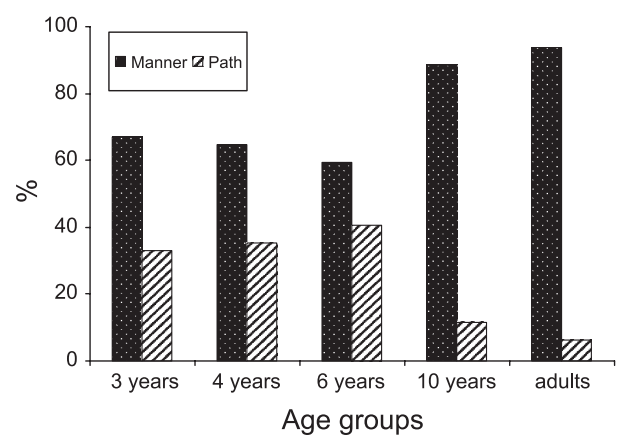

Figure 1. Semantic content of main verbs for target events as a function of age

Figure 1 shows how frequently PATH and MANNER were expressed in the main verb as a function of age. ${ }^{6}$ Main verbs expressed MANNER more frequently than PATH at all ages ( $77 \%$ vs. $23 \%$ overall). Examples (20) and (21) show two typical sentences from German speakers who combine MANNER-verbs with PATH-devices. However, PATH-verbs were not infrequent among young children $(29 \%$ at three years, $30 \%$ at four years, $37 \%$ at six years, in comparison to $15 \%$ at ten years), as illustrated in (22). With increasing age, MANNER-verbs became clearly most frequent, particularly at ten years (87\%) and in the adults' group (94\%). Post-hoctests (Bonferroni) comparing uses of MANNER verbs showed a significant difference between ages six and ten years $(\mathrm{p}<.05)$, but none between ages three to six years, nor between 10 -year-old children and adults.

(20) Die hüpft da, krabbelt auf zum Käse rauf. (3 years)

'She bounces there, crawls on to the cheese up.'

(21) Das Eichhörnchen springt zu dem Baum und klettert hinauf und kriecht in das Loch 〈und geht $\rangle[/ /]$ und hüpft wieder raus und runter. $(6 \text { years })^{7}$

'The squirrel jumps to the tree and climbs up and creeps into the hole $\langle$ and goes $\rangle[/ /]$ and bounces then out and down.'

(22) Die geht auf den Stängel und geht auf das Blatt und esst es ein bisschen und geht wieder runter. (6 years)

'She goes on the stick and goes on the leaf and eats it a little bit and goes again down.'

6. Very few German verbs express MANNER and PATH simultaneously, as for example steigen ('to climb up') or tauchen ('to dive [down]') . Since these verbs were extremely scarce in our data, we did not distinguish them from simple MANNER-verbs.

7. The symbol $[/ /]$ marks a self-correction concerning the passage shown between pointed brackets \langle\rangle . 
5.1.2. Other devices. We now turn to all linguistic procedures that expressed spatial information outside of the main finite verb (included among "other" devices, see coding above). Table 1 shows the mean number of these devices that were used in each age group within one response. This number increased with age, particularly after six years. Age comparisons in this respect showed significant increases between ages six and ten $(\mathrm{p}<.05)$, as well as between ten-year-olds and adults $(\mathrm{p}<.05)$, but no significant differences between ages three and six.

Table 1. Number of devices outside of main verbs for target events as a function of age*

\begin{tabular}{lll}
\hline Age groups & Total number of devices & Number of devices per event \\
\hline 3 years & 14,58 & 1,21 \\
4 years & 14,42 & 1,20 \\
6 years & 13,67 & 1,14 \\
10 years & 17,08 & 1,42 \\
Adults & 19,27 & 1,75 \\
\hline
\end{tabular}

* Number of devices per utterance.

In their verbalizations of up- and down-motion, participants used either one satellite as in example (23) or more as in (24) and (25). On average, adults used 1,75 devices per utterance, as compared to 1,21 at three years. Nevertheless, even some of the children at three years produced as many devices as adults.

(23) Die klettert auf die Blume. (3 years)

'She climbs on the flower.'

(24) Das krabbelt hoch zum Baum. (3 years)

'It crawls up to the tree.'

(25) Wir haben eine Raupe, die sich im Garten bewegt, und sich dann auf einen Stängel raufhangelt [...]. (adult)

'We have a caterpillar that moves in the garden, and then clings on[on] a stripe.'

Figure 2 further shows the distribution of other devices within each age. In all age groups particles were most frequent, but tended to decrease with age (from $75 \%$ at three years to $57 \%$ at adult age). Prepositional phrases tended to increase between ages three $(9 \%)$ and six $(24 \%)$, then to decrease until adult age $(12 \%)$. However, no age differences were significant for either of these types of devices. As for the third residual category, consisting above all of adverbs, it was rather infrequent until six years $(8 \%$ to $14 \%)$, but increased thereafter until adult age (31\%). Age 


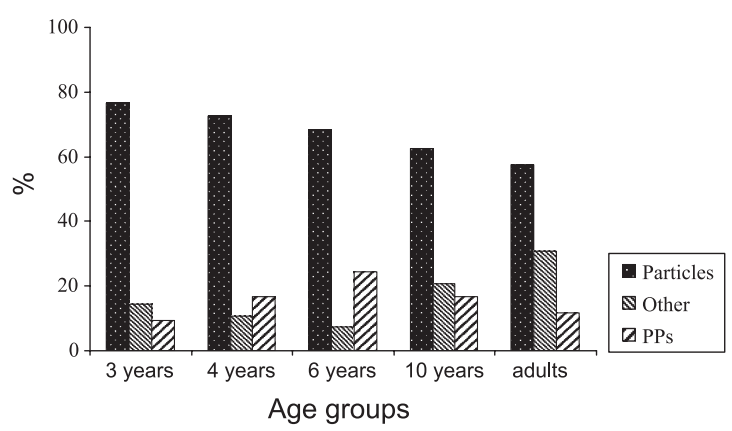

Figure 2. Types of devices outside of main verbs for target events as a function of age

comparisons showed significant increases in these devices between six and ten years $(\mathrm{p}<.05)$, as well as between age ten and adults $(\mathrm{p}<.05)$. No other age differences were significant.

With respect to the semantic information encoded in these linguistic devices, overall $80 \%$ expressed PATH (as in (18) to (20) above), as compared to only 1\% MANNER and 19\% other relevant information (for instance information about the setting). As expected, PATH devices were significantly more frequent than MANNER devices (T-Test, $\mathrm{df}=59, \mathrm{p}=.001)$ and the remaining category mostly concerned information about the setting and the ground, e.g., hier ('here') or auf einer Wiese ('in a meadow'). As shown in Figure 3, the same pattern was observed within each age group.

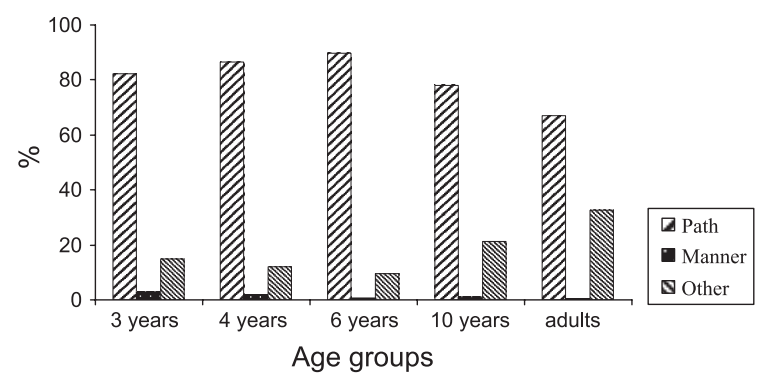

Figure 3. Semantic information expressed in other devices for target events as a function of age

Age comparisons showed no significant differences in the frequencies of PATH devices, despite a slight increase from ages three to six $(82 \%$ to $90 \%$ ) and decrease thereafter ( $78 \%$ at age ten, $67 \%$ among adults). The 
residual class of devices, for example those that provided general locations (other than particles and prepositional phrases) increased with age, showing more frequent uses by adults $(33 \%)$ than by children in any age group (three years $15 \%$, 4 years $12 \%$, six years $10 \%$, ten years $21 \%$ ). As illustrated in examples (26) and (27), this difference between young children and adults mainly concerned information about the setting and the ground.

(26) Das krabbelt da hoch, dann holt sie den Käse und dann geht sie runter. (4 years)

'It crawls up there, then it takes the cheese and then it goes down.'

(27) Die Katze ähm springt an einem Telefon(mast), nein an einem Strommast und ähm krabbelt dann hoch und klaut sich ein Ei aus dem Nest, also das stubst das Ei runter und das Ei fällt auf den Boden, das Ei bricht entzwei und die Katze springt runter und leckt dann das Ei auf. (adult)

'The cat ehm jumps at a telephone (pole), no at a power pole and ehm then crawls up and nicks an egg from the \# nest, well it nudges the egg down and the egg falls to the ground, the egg breaks in two and the cat jumps down and then licks the egg.'

\subsection{Control items}

Figure 4 shows the semantic information that was expressed in motion verbs with control items across the different age groups. At all ages the great majority of verbs expressed MANNER rather than PATH (overall 91\% vs. $9 \%$ ). Despite slight variations in this respect, no age differences were significant. Examples (28) to (31) show a great variety of different MANNER-verbs across ages. In comparison, regardless of age, very few responses contained any other device outside of the main verb, except for occasional locative expressions. No analysis of light verbs is presented for control items, since these verbs were very rare with these items.

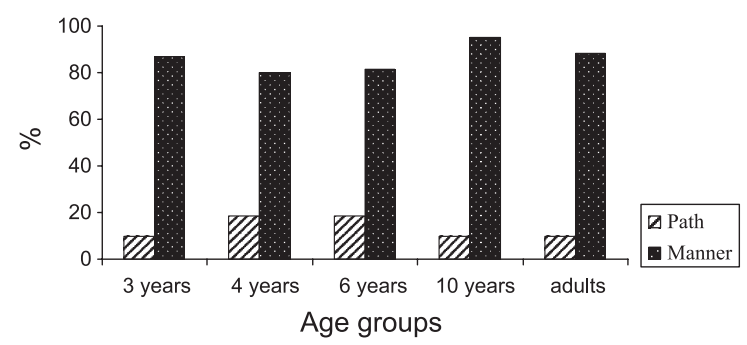

Figure 4. Semantic information in main verbs used for control items as a function of age 
(28) Die springt. (3 years)

'She jumps.'

(29) Die ist so gekrabbelt. (4 years)

'She has crawled like this.'

(30) Die Robbe, die robbt halt so ja, die Raupe, da. (10 years)

'The seal, it crawls just like this, yes, the caterpillar, there.'

(31) Der Bär tapst. (adult)

'The bear lumbers.'

A final analysis compared the types of motion verbs that were used in relation to target and control items. Table 2 shows the number of different lexemes (types) that were used for each item type. In both cases the number of lexeme types remained stable between ages three and six (8-9 types), then increased slightly with target items (10-11 types) and drastically with control items (17 types). However, although children's productive lexicon seems to undergo an explosion between ages six and ten, note that they produced some verbs that were not used by adults, e.g., robben ('to crawl') or schrubben ('to scrub') for the motion of the caterpillar. Moreover, three neologisms were found in the data: raupen, which might be derived from the noun Raupe ('carterpillar') to mean 'to move as a caterpillar'; kraupen, which probably fuses the verb krabbeln ('to crawl') and the noun Raupe ('carterpillar'); tappeln, which probably combines the verbs tappen ('to go falteringly') and tippeln ('to trip').

Table 2. Number of different motion verb lexemes (types) as a function of age

\begin{tabular}{lcc}
\hline Age groups & Target items & Control items \\
\hline 3 years & 9 & 8 \\
4 years & 9 & 9 \\
6 years & 9 & 9 \\
10 years & 11 & 17 \\
adults & 10 & 17 \\
\hline
\end{tabular}

\section{Discussion}

\subsection{Lexicalization patterns in German and other child languages}

Our experiment examined how German children and adults described voluntary motion events, with particular attention to the expression of PATH and MANNER in relation to up and down motion. As expected, the results showed that speakers mostly encoded MANNER in finite verbs and PATH in other linguistic devices outside of the verb. This first result was 
observed at all ages from the youngest age (three years) to adult age. As predicted, these observed patterns are in line with the proposal that German (like other satellite-framed languages) invites speakers to simultaneously focus on both MANNER and PATH.

Additional qualitative information shows that German speakers were greatly concerned with MANNER of motion. First, as illustrated in (32) and (33), self-corrections were observed at all ages from the youngest to the oldest age group, showing that in the majority of cases speakers were searching for the motion verb that exactly corresponded to particular motion events.

(32) $[\ldots]$ ähm jetzt die Raupe, die ist 〈auf den Stängel hochgegangen hat das $>[/ /]$ auf den Stängel hochgekrabbelt 〈und die> [//] und hat das Blatt angebissen. (4 years)

' $[\ldots]$ eh now the caterpillar she $\langle$ went up on the stalk, has $\rangle[/ /]$ she climbed up on the stalk $\langle$ and she $\rangle[/ /]$ and took a bit of the leaf.'

(33) Ein Eichhörnchen krabbelt, also klettert 〈einen Berg $\rangle$ [//] äh einen Baum rauf. (Adult)

'The squirrel crawls, so climbs up 〈on a mountain〉 [//] eh on a tree.'

Second, speakers used a wide range of MANNER verbs in all age groups, sometimes involving very subtle nuances, for instance tappen, tippeln or trippeln (all of which may be translated into English as 'to go falteringly' or 'to trip'). Furthermore, they used a great number of different verbal particles, most of which expressed different aspects of PATH, for example contracted particles such as drauf or hinunter containing up to three different types of semantic information, as illustrated in (34):

$\begin{array}{ll}\text { drauf: } & d(a)+(\text { he }) r+a u f \\ \text { da ('there'): } & \text { general location in which motion takes place } \\ \text { her ('towards'): } & \text { deixis } \\ \text { auf ('up'): } & \text { direction (along a vertical axis) } \\ \text { hinunter: } & \text { hin }+ \text { unter } \\ \text { hin ('towards'): } & \text { deixis } \\ \text { unter ('down'): } & \text { direction of the movement (vertical axis) }\end{array}$

Finally, speakers encoded PATH information not only in particles, but also in many other linguistic devices, such as prepositional phrases or adverbs, thereby producing very detailed PATH descriptions, as illustrated in (35).

(35) [...] von rechts kommt eine Raupe ins Bild, bewegt sich auf einen Halm $z u$, klettert hinauf bis zum ersten Blatt [...]. (Adult) 
'[...] a caterpillar comes from the right into the screen, moves towards a blade, climbs up to the first leaf [...].'

A comparison of these results with those that were previously obtained in the same experimental situation for French and English (Hickmann et al. 2009) follows our hypotheses. As predicted on the basis of Talmy's typology, our results concerning German are similar to those reported for English and differ significantly from those reported for French. Like German speakers, English-speaking adults and children predominantly express MANNER and PATH together within their utterances. They encode MANNER in the main verb and PATH in particles and prepositions (e.g., to crawl up/down). However, children also produce some PATH-only responses in which they express sheer motion in the verb and PATH in satellites (e.g., to go up/down). In contrast, although French adults frequently express MANNER and PATH together, they do so less frequently and less systematically than English-speaking adults. French children tend to focus on PATH alone, encoding this information in the main verb (e.g., monter 'to ascend', descendre 'to descend') and they either do not express MANNER or express this information outside of the verb (in gerunds e.g., descendre en courant 'to descend by running' or in adverbials e.g., monter avec les pattes 'to ascend with the paws'). Differences also occur at all ages as a function of event type. MANNER-only responses are rare in both languages and at all ages, with the exception of boundary-crossing events (see above). In addition, French provides a very frequent verb that simultaneously encodes MANNER and upwards direction ( grimper 'climb up') inviting French speakers to produce more MANNER+PATH responses with upward motion than with downward motion.

A couple of additional points arose during our analyses of some German spatial devices and remain open. First, with respect to motion verbs, previous linguistic analyses of German (particularly Haggblade 1994; Weber 1983 among others) may need substantial qualifications, particularly in relation to light verbs. Although the classification of gehen ('to go') as a light verb is probably uncontroversial in most cases, its semantic content may differ across contexts (also see Di Meola 1994, for a study of kommen and gehen). For example, as illustrated in (36), this verb may encode MANNER information, particularly when used to describe motion in relation to the control items. In other contexts such as (37), however, it can encode information about deixis, particularly in descriptions of departures from the screen (which were not analyzed in the present study).

(36) Experimenter: Und die kleine Maus? 'And the mouse?' Child: Die geht. (4 years) 'She goes [=walks].' 
(37) Die Raupe frisst ein bisschen vom Blatt wo sie hochgegangen ist, dann geht [?] sie wieder runter und geht [= geht weg]. (4 years)

'The caterpillar eats a bit of the leaf where it went up, then it goes down under and goes [=goes away].'

Second, following Haggblade (1994: 43), our analysis included information about the setting and the ground among the semantic information that was encoded by subjects' uses of linguistic devices outside of the verb. However, as suggested by some authors (e.g., Talmy 1985, 2000 or Slobin 1996, 2003b), this type of information is of a different nature and should not be included as part of the semantics of motion per se in the class of satellites. Excluding such spatial devices would imply a more conservative coding resulting in fewer satellites overall but in proportionally more satellites expressing PATH. It would therefore not invalidate our analysis and on the contrary increase the satellite-framed properties of German observed at all ages in our data.

\subsection{Developmental progressions in German}

Our results show the same lexicalization patterns among children and adults. From the earliest age tested onward (three years), German speakers express MANNER and PATH in compact utterances, encoding MANNER in the finite verb and PATH mostly in verbal particles. As predicted, MANNER is as salient to them as PATH, a result that follows from the typological properties of German as a satellite-framed language. Since German systematically encodes MANNER in the main verb, children seem to pay attention to this information from three years on and also encode it in their motion event descriptions.

Nonetheless, several developmental progressions also occur, revealing a leap particularly between the ages of six and ten years. A first progression concerns an increase in the semantic and syntactical complexity of children's utterances. For instance, the complexity of linguistic devices encoding information outside of the main verb increased with age. As expected, young children most often used adverbs (e.g., da 'there', hier 'here') to locate the motion event and simple particles (e.g., rauf 'up', runter 'down') to describe path. It is only at around six years that prepositional phrases (e.g., auf dem Boden 'on the ground', auf den Baum 'on the tree') are used more frequently and with relative ease.

This developmental progression was observed in relation to the devices that were used outside of the main verb. Although the semantics of these devices do not change over time, they are used increasingly with age. Children mostly use PATH particles that can be easily combined with a great number of different verbal stems. As children learn other devices, 
they first acquire particles as undifferentiated and whole linguistic entities that are not analysed (neither morphologically nor semantically) and therefore produce frequent contracted forms (drauf 'onto', nunter 'down' etc.). Qualitative analyses show that each child uses only one single form within a given set of particles differing with respect to the deictic element hin/her and their corresponding reduced forms $n$ - $/ r$ - (e.g., nauf, nunter, nüber; rauf, runter, rüber; herauf, herunter, herüber). From very early on, young children use semantically complex satellite forms, even though we cannot assume that they know all semantic contrasts within a given paradigm (e.g., hinauf/herauf).

Second, the data show some changes across age groups with respect to verb use. Although motion verbs are quite diverse in all age groups, reflecting in particular the highly salient nature of MANNER in German (as in other satellite-framed languages), children between three and six years also make frequent uses of light motion verbs (particularly gehen 'to go'), thereby producing utterances that are morphologically and semantically simpler.

Finally, as children get older, they show an increasing ability to organize discourse, as shown by the fact that they gradually learn to specify information about the setting and the ground. Unlike adults, children often do not provide sufficient information for their listener to reconstruct the spatial universe of discourse. They typically only describe motion itself, without any spatial anchoring, for example without specifying the general location in which these events occurred, nor the source and goal locations implied by some of these events, making it difficult for their listener to interpret changes of location. A very similar developmental progression was also observed in previous analyses of children's narratives (Hickmann 2003) across several different child languages (English, French, German, Chinese).

Thus, although language-specific factors strongly contribute to shaping German children's lexicalization patterns when they verbalize motion events, these factors alone cannot account for the fact that their responses show an increase in semantic density and in syntactic complexity. Other factors must clearly play a role in how these children's spatial language changes with age. Thus, children's cognitive system matures during language acquisition and some of these changes presumably underlie some changes in their linguistic system, for example an increase in their memory, processing, reasoning, and planning capacities, all of which are involved in complex discourse activities. In addition, the most striking developmental changes were observed at around six years, which corresponds to the age at which German children start school and are challenged in the domain of language. 


\section{Conclusion}

The pattern found for German children is consistent with the one reported in other satellite-framed languages such as English and quite different from the one reported in verb-framed languages such as Spanish or French. When describing motion events, young children learning satellite-framed languages systematically express both MANNER and PATH within their utterances. The typological properties of their mother tongue simplify this task by compactly packaging these two types of information in constructions comprising linguistic devices that are among the first morphemes to be mastered during language acquisition (verbal particles). Depending on their language, then, speakers within a given speech community choose to talk about or to ignore particular aspects of denoted situations. This process of selection presumably leads them to build up spatial representations that are partially characteristic of their language. In this sense, our results support the view that children partially construct the semantics of space in accordance with the language-specific characteristics of their mother tongue. Future research needs to address further questions concerning the depth of such typological constraints on speakers' representations beyond language use.

Received 1 March 2009

Revision received 25 November 2009

University of Munich/

University of Paris

\section{References}

Altmann, Hans and Silke Kemmerling. 2005. Wortbildung fürs Examen. Göttingen: Vanderhoeck and Ruprecht.

Antell, Sue Ellen and Albert Caron. 1985. Neonatal perception of spatial relations. Infant Behaviour and Development 8. 15-23.

Bamberg, Michael. 1994. Development of linguistic forms: German. In Ruth Berman and Dan I. Slobin (eds.). Relating events in Narrative: A crosslinguistic developmental study, 189-284. Hove: Erlbaum.

Bowerman, Melissa. 1996a. Learning how to structure space for language. A crosslinguistic perspective. In Paul Bloom (ed.). Language and space, 385-436. Cambridge: MIT Press.

Bowerman, Melissa. 1996b. The origins of children's spatial semantic categories: Cognitive versus linguistic determinants. In John J. Gumperz and Stephen Levinson (eds.). Rethinking linguistic relativity, 145-176. Cambridge: Cambridge University Press.

Bowerman, Melissa and Soonja Choi. 2003. Space under construction. Language-specific categorization in first language acquisition. In Dedre Gentner and Susan Goldin-Meadow (eds.). Language in Mind. Advances in the study of language and thought, 387-427. Cambridge: MIT Press.

Choi, Soonja and Melissa Bowerman. 1991. Learning to express motion events in English and Korean: the influence of language-specific lexicalization patterns. Cognition 41. 83-121. 
Croft, William, Johanna Baraddal, Willem Hollmann, Violeta Sotirova and Chiaki Taoka. 2008. Revising Talmy's typological classification of complex events. Unpublished draft: http://www.unm.edu/ wcroft/WACpubs.html

Di Meola, Claudio. 1994. Kommen und gehen. Eine kognitiv-linguistische Untersuchung der Polysemie deiktischer Bewegungsverben. Tübingen: Niemeyer.

Gentner, Dedre. 1978. On relational meaning. The acquisition of verb meaning. Journal of Child Development 49. 988-998.

Haggblade, Elisabeth. 1994. Die Lexikalisierung von semantischen Komponenten in den Bewegungsverben. Berlin: microfiche version.

Hickmann, Maya. 2006. The relativity of motion in first language acquisition. In Hickmann, Maya and Stéphane Robert (eds.), Space across languages: linguistic systems and cognitive categories, 281-308. Amsterdam/Philadelphia: John Benjamins.

Hickmann, Maya. 2007. Static and dynamic location in French: developmental and crosslinguistic perspectives. In Michel Aurnague, Maya Hickmann and Laure Vieu (eds.), Spatial entities in language and cognition, 205-231. Amsterdam/Philadelphia: John Benjamins.

Hickmann, Maya, Pierre Taranne and Philippe Bonnet. 2009. Motion in first language acquisition: manner and path in French and English child language. Journal of Child Language, 36 (4). 705-741.

Johnston, Judith and Dan Isaac Slobin. 1979. The development of locative expressions in English, Italian, Serbo-Croatian and Turkish. Journal of Child Development 6, 530545.

Landau, Barbara and Ray Jackendoff. 1993. What and Where in spatial language and spatial cognition. Behavioral and Brain Sciences 16(2). 217-38.

Mandler, Jean M. 1996. Preverbal Representation and Language. In Paul Bloom (ed.), Language and space, 365-384. Cambridge: MIT Press.

Piaget, Jean and Bärbel Inhelder. 1947. La représentation de l'espace chez l'enfant. Paris: Presses Universitaires de France.

Slobin, Dan I. 1996. From "thought and language" to "thinking for speaking". In John J. Gumperz and Stephen Levinson (eds.), Rethinking linguistic relativity, 70-96. Cambridge: Cambridge University Press.

Slobin, Dan I. 2003a. Language and thought online: cognitive consequences of linguistic relativity. In Dedre Gentner and Susan Goldin-Meadow (eds.), Language in mind: Advances in the study of language and thought, 157-191. Cambridge, MA: MIT Press.

Slobin, Dan I. 2003b. The many ways to search for a frog. In Sven Strömqvist and Ludo Verhoeven (eds.), Relating events in narrative: Typological and contextual perspectives, 219-257. New Jersey: Erlbaum.

Slobin, Dan I. 2006. What makes manner of motion salient: Explorations in linguistic typology, discourse, and cognition. In Maya Hickmann and Stéphane Robert (eds.), Space across languages: Linguistic systems and cognitive categories, 59-81. Amsterdam: John Benjamins.

Spelke, Elizabeth S. 2003. What makes us smart? Core knowledge and natural language. In Dedre Gentner and Susan Goldin-Meadow (eds.), Language in mind: Advances in the study of language and thought, 277-311. Cambridge, MA: MIT Press.

Talmy, Leonard. 1983. How language structures space. In Herbert Pick and Linda Acredolo (eds.), Spatial Orientation, 225-282. New York: Plenum.

Talmy, Leonard. 1991. Path to Realization. A Typology of Event Conflation. In J. Sutton and C. Johnson (eds.), Proceeding of the seventeenth annual meeting of the Berkeley Linguistic Society, 480-519. Berkeley.

Talmy, Leonard. 2000. Towards a cognitive semantics: Concept structuring systems. Cambridge: Cambridge University Press. 
Talmy, Leonard. 1985. Lexicalization Patterns. Semantic structure in lexical forms. In Timothy Shopen (ed.), Language typology and syntactic description: Grammatical categories and the lexicon, Vol. 3, 57-149. Cambridge: Cambridge University Press.

Tschander, Ladina. 1999. Bewegung und Bewegungsverben. In Ipke Wachsmuth and Bernhard Jung (eds.), Proceedings der 4. Fachtagung der Gesellschaft für Kognitionswissenschaft, 25-30. Bielefeld: Sankt Augustin.

Weber, Gerhard. 1983. Untersuchungen zur mentalen Repräsentation von Bewegungsverben. Merkmale, Dimensionen und Vorstellungsbilder. Dissertation. Hannover.

Whorf, Benjamin Lee. 1956. Language, thought and reality. Cambridge, MA: MIT Press.

\section{Appendix}

Stimuli

\section{T: Target items - up and down}

(T1) A squirrel runs to a tree, up into and out of a hole in the tree, down, and away.

(T2) A caterpillar crawls to a plant, up the stalk to eat a piece of leaf, down, and away.

(T3) A bear walks to a tree, climbs up to a beehive to get some honey, climbs down to eat it, and walks away.

(T4) A cat runs to a telephone pole, jumps up to a bird's nest, drops an egg, jumps down to lick the egg, and runs away.

(T5) A mouse tiptoes to a table, climbs up to take a piece of cheese, slides down, and tiptoes away.

(T6) A monkey walks to a banana tree, climbs up to take a banana, then slides down and walks away.

\section{C: Control items - MANNER maximally salient}

(C1) squirrel running; (C2) caterpillar crawling; (C3) bear walking; (C4) cat running; (C5) mouse tiptoeing; (C6) kitten running. 